\title{
NILAI KEAGAMAAN CANDI GEDONG I MUARA JAMBI SEBAGAI SUMBER PEMBELAJARAN DI SMA AISYIYAH 1 PALEMBANG
}

\author{
Oleh: Diah Adyama Nareta* \\ *Mahasiswa Program Studi Pendidikan Sejarah FKIP Universitas PGRI Palembang
}

\begin{abstract}
ABSTRAK
Candi Gedong I Muara Jambi yang kaya akan peninggalan dan memiliki nilai keagamaan namun belum semua data dan informasi sejarah tersebut dapat dimanfaatkan dalam pembelajaran sejarah di sekolah. Adapun Fokus Penelitian adalah nilai keagamaan Candi Gedong I Muara Jambi dan yang menjadi Subfokus penelitian ini adalah sumber pembelajaran sejarah di SMA Aisyiyah 1 Palembang. Sedangkan permasalahan dalam penelitian ini adalah: Bagaimanakah nilai keagamaan Candi Gedong I Muara Jambi dapat dijadikan sebagai sumber pembelajaran sejarah di SMA Aisyiyah 1 Palembang? tujuan dari penelitian ini yaitu: untuk mengetahui nilai keagamaan Candi Gedong I Muara Jambi yang dapat dijadikan sebagai sumber pembelajaran sejarah di SMA Aisyiyah 1 Palembang. Metode yang digunakan dalam penelitian ini adalah metode deskriptif kualitatif. Berdasarkan hasil analisis data yang telah dilakukan Nilai keagamaan Candi Gedong I Muara Jambi merupakan salah satu warisan bersejarah agama Budha yang bernilai sangat tinggi yang dapat dijadikan sumber pembelajaran sejarah di SMA Aisyiyah 1 Palembang. Temuan-temuan yang terdapat di Candi Gedong I Muara Jambi menunjukkan bahwa candi ini menjadi suatu tempat peribadatan agama Budha aliran Mahayana.
\end{abstract}

Kata Kunci: Nilai Keagamaan, Candi Gedong I, Sumber Pembelajaran Sejarah

\section{A. PENDAHULUAN}

Menurut Poesponegoro (2004:1) kepulauan Indonesia terletak antara $50540^{\circ}$ Lintang Selatan, serta 95०01' Bujur Timur dan $141^{\circ} 02^{\prime}$ Bujur Timur. Oleh karena itu, Indonesia termasuk daerah khatulistiwa dan berada di daerah hembusan angin muson Indo-Australia. Adanya dua musim sebagai gejala tetap dalam iklim, berpengaruh pada berbagai aspek dalam kehidupan penduduk kepulauan Indonesia. Misalnya pada pola pertanian, pola pelayaran, dan aspek-aspek lain yang dipengaruhi iklim. Kepulauan Indonesia terletak di jalur laut utama antara Asia bagian timur dan selatan. Campuran rasial di Hindia sangat menarik karena kebetulan tiga ras utama umat manusia berdiam di benua-benua sekitarnya.

Menurut Hendarata (2012:1) Provinsi Jambi terletak di daerah khatulistiwa antara $0,45^{\circ}$ garis Lintang Utara $2.45^{\circ}$ garis Lintang Selatan dan $101.10^{\circ}$ sampai 104.55 Bujur Timur. Provinsi Jambi yang terdiri dari enam daerah tingkat II, yaitu
Kotamadya Jambi, Kabupaten Batanghari, Kabupaten Sarobangun Sangko, Kabupaten Bungo Tubo, Kabupaten Tanjung Jabung dan Kabupaten Kerinci, terbagi menjadi 37 Kecamatan dengan 1292 desa, luas $53.244 \mathrm{~km}^{2}$. Secara topografis ia dapat dibagi atas tiga daerah, yaitu daerah pantai, daerah dataran rendah, dan daerah dataran tinggi. Provinsi Jambi yang terletak di Pinggang Pulau Sumatera, luasnya $53.244 \mathrm{~km}$ (Wiyoso, 1982:1).

Jambi merupakan salah satu provinsi yang mempunyai banyak temuan arkeologis terutama temuan pada masa prasejarah, Hindu-Buddha, Islam dan Kolonial. Di hampir semua Kabupaten di Provinsi Jambi mempunyai potensi temuan arkeologis. Kabupaten yang memiliki temuan arkeologis di antaranya adalah Kabupaten Muaro Jambi, Kabupaten Kerinci, Kabupaten Merangin. Jambi dan sekitar daerah alur sungai Batanghari sudah lama dikenal sebagai daerah yang penting secara internasional ini ternyata 
dari berita-berita asing seperti Cina dan Arab di samping dari sumber dalam negeri seperti kitab Nagarakertagama dan prasasti. Pada 664-665 Mo-Lo-jeu telah mengirim utusan ke negeri Cina. Pada tahun 853-871 Cham-pi Jambi mengirim armada dagang. Kota yang dianggap penting oleh pedagang Arab antara lain Zabag (Muara Sabak). Dari berbagai artefak yang ditemukan, terutama keramik dapat diketahui bahwa di gugusan percandian Muara Jambi telah berlangsung aktivitas manusia sejak abad ke-9 dan setelah abad ke-16 terjadi perubahan dan kemunduran drastis.

Menurut Utomo (2011:134) situs Muara Jambi secara administratif terletak di Desa Muara jambi, Kecamatan Marosebu, Kabupaten Muara Jambi, Provinsi Jambi dan secara astronomis terletak pada koordinat $103041^{\prime} 15^{\circ}$ BT dan 1028'310 LS. Situs Muara Jambi yang ketinggiannya sekitar 14 meter d.p.l terletak di suatu daerah dataran yang merupakan daerah tanggul alam dari Sungai Batanghari. Di sebelah utara terdapat rawa-rawa yang ketinggiannya sekitar 10 meter d.p.l. Keadaan tanah pada umumnya sama seperti pada Situs Simpang (A2cT) yang mempunyai kedalaman efektif tanah lebih dari $90 \mathrm{~cm}$, dengan tekstur sedang, tergenang air secara periodik, dan tidak ada erosi. Situs Percandian Muara Jambi mempunyai luas sekitar 11 kilometer persegi.

Sejarah pemahaman Tuhan dan kerohanian Indonesia mengalami perubahan penting ketika agama-agama India masuk Indonesia sekitar abad pertama Masehi. Perubahan budaya yang berdasarkan sistem kepercayaan masingmasing etnik yang terjadi dengan masuknya agama-agama India, tidak mudah dipahami tanpa mengetahui kepercayaan masing-masing. Masuknya budaya India lewat agama menimbulkan perubahan besar dalam munculnya lembaga kenegaraan baru, yakni kerajaan.
Lembaga kenegaraan yang asli bersifat kampung, baik kecil maupun besar. Pada masyarakat sawah dapat diduga munculnya negara-negara kampung besar. Namun, pada masyarakat ladang berbentuk skalanya lebih kecil dan masyarakat peramu serta kelautan tentu lebih kecil-kecil lagi. Wilayah budaya Primordial suku Melayu di Sumatera yang ladang dan kelautan Agama India yang diterima masyarakat Melayu adalah Budha Mahayana aliran Tantra. Khususnya Aran Wajrayana, seperti tampak dari prasastiprasasti yang ditinggalkannya. Kerajaankerajaan Hindu di Melayu hidup dari perniagaan, yakni menyediakan pelabuhanpelabuhan persinggahan atau pusat dagang di Asia Tenggara, bahkan internasional kedudukannya mirip dengan Singapura sekarang (Sumardjo, 2013:29).

Menurut Arismunandar (2009:54-56) Bukti-bukti yang berupa kebudayaan material (monumen, arca, relief, prasasti dan lain-lain) yang ditemukan di Pulau Sumatera banyak yang memperlihatkan jejak agama Budha Mahayana, dan terbatasnya pengaruh agama Hindu. Uraian prasasti-prasasti dari masa Sriwijaya menunjukkan adanya napas Budhiesme yang cukup kentara kentara, begitupun sejumlah penemuan arca Budha dari kurun waktu awal penyebaran kebudayaan India hingga masa yang lebih kemudian menunjukkan suburnya perkembangan Agama Budha Mahayana. Temuan sejumlah besar arca batu dan logam di wilayah Palembang dan sekitarnya membawa kepada kesimpulan bahwa pusat Kerajaan Sriwijaya berdasarkan berita Cina pada abad ke-7 Masehi dapat ditafsirkan bahwa Sriwijaya semula berkembang agama Budha Hinayana dan Mahayana. Dalam era selanjutnya justru Budha Mahayana yang berkembang secara pesat, dan menenggelamkan Budha Hinayana. Sangat mungkin agama Budha Mahayana disokong oleh dinasti raja-raja yang kuat 
berwibawa dan mampun mengembangkan kekuasannya di wilayah Jawa dan Sumatera, dinasti itu tidak lain Sailendrawangsa.

Hal yang menarik selanjutnya terjadi pada kurun waktu yang lebih muda, agaknya pusat agama Budha Mahayana bergeser ke wilayah Jambi. Di tepian sungai Batanghari dijumpai puluhan kepurbakalaan yang terbuat dari bata, monumen yang terdapat di situs tersebut lazim dinamakan candi juga, namun arsitekturnya berbeda dengan candi-candi yang terdapat di Jawa Tengah atau Jawa Timur. Penduduk setempat menamakan candi-candi itu dengan Candi Astano, Tinggi, Gumpung, Kembar Batu, Kedaton, Koto Mahligai, dan lain-lain. Para ahli untuk sementara ini menempatkan kronologi situs Muara Jambi antara abad ke-12- $13 \mathrm{M}$, didasarkan pada temuan keramik Cina, bentuk arsitektur bangunan, dan gaya seni arcanya. Menilik beranekaragamnya bangunan yang corak keagamaan, maka dapat diduga bahwa situs Muara Jambi pada masanya merupakan pusat aktivitas agama Budha Mahayana yang cukup ramai (Munandar, 2009:54).

Memperhatikan

kurikulum berkarakter mengenai materi Hindu-Budha yang ada di silabus SMA Kelas XI, setelah dikaji materi mengenai peninggalan agama Hindu-Budha di Indonesia tidak begitu dalam membahas Nilai keagamaan candi, selain itu dalam pendidikan yang dilaksanakan di Sekolah Menengah Atas dalam proses belajar mengajar lebih terpaku pada buku panduan yang telah disediakan oleh pemerintah, dan kurang memanfaatkan sumber yang ada di lingkungan sekitar sebagai sumber pembelajaran sejarah. seperti salah satunya peninggalan di situs Muara Jambi yaitu candi gedong satu, yang terletak di Muara Jambi.

Berdasarkan Uraian diatas, maka penulis bermaksud unuk mengadakan penelitian dengan judul "Nilai Keagamaan
Candi Gedong I Muara Jambi Sebagai Sumber Pembelajaran Sejarah".

\section{B. METODE PENELITIAN}

Peneliti menggunakan metode penelitian deskriptif kualitatif, yang menggunakan cara mengumpulkan sumber-sumber secara sistematis dan menggunakan sumber data secara mendalam. Berdasarkan rumusan masalah, penelitian mendeskripsikan mengenai Candi Gedong I Muara Jambi sebagai sumber pembelajaran sejarah di SMA Aisyiyah 1 Palembang. Untuk memahami hal tersebut, dilakukan penelitian mengenai nilai keagamaan Candi Gedong I Muara Jambi yang dapat dijadikan sebagai sumber pembelajaran sejarah.

\section{Data dan Sumber Data}

Data dan sumber data dalam penelitian ini adalah:

a. Informan/Narasumber dalam penelitian ini adalah Bapak Zainuddin selaku masyarakat di sekitar Candi Gedong I Muara Jambi, guru Sejarah SMA Aisyiyah 1 Palembang, Ibu Mery Ahca, S.Pd.

b. Buku-buku yang relevan mengenai Candi Gedong I Muara Jambi dan silabus sejarah kelas $X$ SMA Aisyiyah 1 Palembang.

c. Observasi lapangan dilakukan di Candi Gedong I Muara Jambi dan SMA Aiyiyah 1 Palembang.

\section{Teknik Pengumpulan Data}

Teknik pengumpulan data yang peneliti gunakan yaitu sebagai berikut:

1. Dokumentasi

Dalam pengumpulan data pada penelitian mengumpulkan dan menyelidiki data-data tertulis tentang Candi Gedong I Muara Jambi yang termuat di dalam laporan-laporan hasil penelitian di Balai Arkeologi Palembang. Selain itu penelitian ini 


\section{Observasi}

juga mengumpulakn data dari buku sejarah SMA Aiyiyah 1 Palembang.

Dalam penelitian ini observasi dilakukan di Candi Gedong I Muara Jambidan di kelas X SMA Aisyiyah 1 Palembang Tahun Ajaran 2016/2017.

\section{Wawancara}

Dalam penelitian ini peneliti melakukan wawancara kepada masyarakat Candi Gedong I Muara Jambi yaitu Bapak Zainuddin dan Ibu Mery Ahca, S.Pd guru sejarah SMA Aisyiyah 1 Palembang.

\section{Teknik Keabsahan Data}

Peneliti menjelaskan bagaimana proses dan teknik yang digunakan untuk memeriksa keabsahan data. Uji keabsahan data dalam penelitian kualitatif meliputi uji Kredibility (validitas Internal), transferability (validitas eksternal), dependability (reliabilitas), dan confirmability (obyektivitas)" (Sugiyono, 2008:366).

\section{Teknik Analisis Data.}

Analisis data dalam penelitian kualitatif ke dalam tiga tahap yaitu kodifikasi data/reduksi data, penyajian data, dan penarikan kesimpulan/verifikasi.

\section{HASIL DAN PEMBAHASAN Candi Gedong IMuara Jambi Letak CandiGedong I}

Menurut Purwanti (2012:43-44) situs Muara Jambi secara administratif terletak di Desa Muara Jambi, Kecamatan Marosebo, Kabupaten Muara Jambi, Provinsi Jambi. Situs ini terletak di tepi Sungai Batanghari, berjarak kurang lebih $25 \mathrm{~km}$ di sebelah timur Kota Jambi. Situs Muara Jambi sudah dikenal Crook sejak tahun 1820 setelah mengunjungi peninggalan purbakala di Muara Jambi dan berbendapat bahwa Situs Muara Jambi dahulunya merupakan sebuah ibukota dari suatu kerajaan. Pendapatnya ini disetujui oleh Schnitger (1937:5-8) yang dalam ekspedisinya telah pula mengadakan penggalian di beberapa candi dan mencatat peninggalan purbakala di situs ini.

Berdasarkan hasil-hasil penelitian yang telah dilakukan sejak tahun 1936 sampai sekarang sudah terkumpul data dari arkeologi dari berbagai jenis dan bentuknya. Temuan berupa pecahan keramik asing dan lokal, prasasti, arca, bangunan candi, manopo, umpak batu, pecahan kaca,manik-manik, mata uang Cina, bata-bata dengan gambar gores dan sebagainya mengidinkasikan bahwa Situs Muara Jambi merupakan situs besar dan diperkirakan merupakam salah satu pusat pemerintahan (kota) di masa lalu seperti yang diamsusikan oleh Shnitger.

Selain temuan di atas, di situs Muara Jambi juga ditemukan kolam-kolam, antara lain Kolam Telago Rajo, yang terletak sekitar 100 meter sebelah tenggara Candi Gumpung. Di samping itu terdapat satu buah kolam lain yang terletak di antara Candi Tinggi dan Candi Gumpung. Pada waktu diadakan pembersihan kolamini ditemukan berbagai temuan keramik Cina dari abad ke-11-13 Masehi diselingi dengan keramik-keramik Belanda dari abad ke-19 Masehi. Berdasarkan hasil poto udara dan penelitian lapangan yang dilakukan oleh BAKOSURTANAL padatahun 1984, 1985 , dan 1990 dapat terungkap adanya jaringan kanal/parit kuno yang dibuat menggelilingi lokasi-lokasi temuan arkeologisnya. Sungai-sungai kecil dan parit-parit yang beberapa di antaranya menunjukkan tandatanda sengaja dibuat tersebut seolah-olah memisahkan kelompok percandian di sini menjadi tiga kelompok. Kelompok pertama terletak di sebelah timur terdiri dari Candi Astano, KembarBatu, Candi Tinggi, Candi Gumpung, yang dipisahkan oleh Sungai Melayu di sebelah barat dan utara, serta Sungai Buluran di sebelah selatan. Kelompok kedua terdiri dari Candi Gedong I dan II, dan Candi Kedaton yang terletakdi tengah, yang seolah-olah dipisahkan oleh Sungai Melayu di sebelah timur dan Sungai 
Terusan di sebelah barat. Kelompok ketiga adalah Candi Mahligai terletak menyendiri di ujung barat laut dengan batas Sungai Berembang di sebelah barat.

Dengan adanya serangkaian penelitian tersebut dapat diketahui bahwa Situs Muara Jambi tidak hanya merupakan lokasi peribadatan bagi para pemeluk agama Buddha, namun juga lokasi pemukiman di masa lalu (Purwanti, 2012:45).

Menurut Latief

berdasarkan kajian atau penelitian secara geologis terhadap daerah Jambi dan sekitarnya, dataran di sekitar Sungai Batanghari merupakan dataran hasil endapan aluvial limbah banjir. Daerah ini diperkirakan dahulunya merupakan pelabuhan yang cukup ramai. Berdasarkan catatan sejarah yang pernah dibuat atau ditulis oleh para musafir Arab dan Cina yang singgah di Sungai Batanghari, diantaranya dalam kitab dinasti Tang disebutkan tentang datangnya utusan dari negara Mo lo yu ke tanah Cina pada tahun 644-655 Masehi. Mo lo yu dapat diidentifikasikan dengan Melayu yang terletak di pantai timur.

Beberapa hal menarik dari kompleks percandian ini adalah seluruh bangunan percandian dibuat dari batu bata. Suatu keadaan yang mirip dengan umumnya bangunan candi-candi Jawa Timur. Dari keadaan lingkungan dan bangunannya terlihat bahwa pendukung atau pembuat bangunan percandian Muara Jambi ini memiliki tingkat penguasaan teknologi yang sudah relatif maju. Pada sekeliling dari setiap bangunan selalu diberi pagar tembok dari batu bata dan di sisi bagian luarnya dikelilingi oleh parit-parit yang berukuran besar. Sehingga apabila terjadi banjir yang berasal dari Sungai Batanghari ketika air pasang tidak akan membanjiri candi-candi tersebut. Hal ini menunjukkan bahwa para pembuat candi-candi tersebut telah menyiapkan suatu sistem pengaturan air yang baik.
Teknik atau cara pembangunan candi-candi tersebut mempunyai keistimewaan yakni pada bagian dalam tubuh candi umumnya diisi dengan batubatu mirip batu pualam dalam ukuran yang kecil dan berwarna putih. Semua batu-batu itu diduga merupakan barang impor sebab di sepanjang Sungai Batanghari tidak ditemukan jenis batu pualam tersebut, hanya berupa pasir, dan tanh rawa yang basah.

Candi-candi yang terdapat pada situs Muara Jambi umumnya berbentuk altar berukuran besar. Pemujaan pada candi-candi di tempat ini dilakukan di atasnya, tidak seperti candi-candi yang terdapat di pulau Jawa di mana tempat pemujaannya terdapat dalam relung tubuh candi (Latief, 1994:44-45).

Menurut Tim Koordinasi Penelitian Sejarah Melayu Kuno (1994:34) dari Candi Gedong II, candi ini terletak sekitar 150 meter arah timurnya. Dari Candi Gumpung berjarak kira-kira 950 meter ke arah barat laut atau sekitar 80 meter di selatan parit buluh. Sebagian besar lingkungan candi masih merupakan hutan primer. Banyak pohon durian dan duku yang tajuknya tinggi tumbuh cukup rapat di sekitar candi. Candi ini dulu dikenal juga sebagai Candi Gudang Garam. Berikut sketsa Candi Gedong I Muara Jambi.

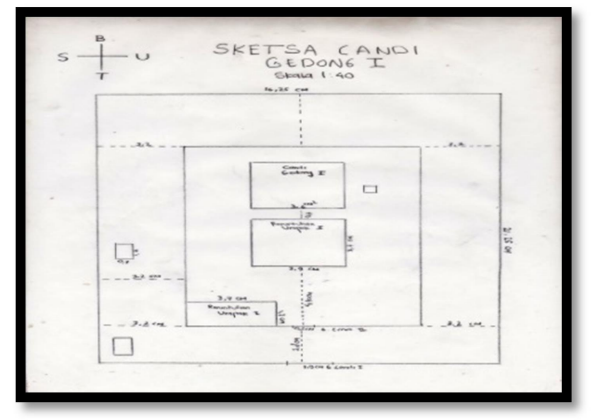

(Gambar: Sketsa Candi Gedong I Muara Jambi, sumber: hasil gambar Refiko Apriansyah).

\section{Kepercayaan Masyarakat di Candi Gedong I}

Agama Buddha aliran Mahayana merupakan kepercayaan yang dianut masyarakat di sekitar candi Gedong I. 
Mahayana sendiri berarti (kendaraan besar) diucapkan oleh pengikut Mahayana yang menyatakan bahwa "kendaraannya cukup besar untuk mengangkut seluruh pengabdian kemanusiaan" (Samad, 1990:52).

Setiap orang bisa masuk Nirwana dengan bantuan dewa-dewa. Padahal sejak semula Sidharta Gautama mengajarkan bagaimana mencapai kebahagian dalam hidup, dia tidak pernah mengajarkan dan menyebut nama Tuhan dan dewa-dewa. Dengan adanya dewadewa atau Bodhisatwa di dalam Buddha maka perbedaan antara Buddha an Hindu makin samar-samar (Erwin, 1990:20).

Tujuan terakhir Mahayana bukanlah mengejar tingkatan Arhat untuk masuk Nirwana, melainkan lebih tinggi lagi, ialah: menjadi Buddha (maka Mahayana disebut pula Buddhayana). Cita-citanya bukanlah untuk mengecap kenikmatan bagi dirinya sendiri, melainkan untuk mengajak dan membimbing orang lain memperoleh kenikmatan itu. Dalam Mahayana jumlah itu sangat diperbanyak, bahkan ditambah lagi dengan mereka-mereka yangsudah menjadi calon Buddha (yaitu para Bodhisattwa). Para buddha dan bodhisatwa dibagi lagi menjadi dhyani buddha/dhyanibodhisatwa yang adanya di langit, dan manusi-buddha/manusi-bhodisatwa yang turun di dunia manusia ini dan langsung membimbing umat manusia (Soekmono, 1973:25).

\section{Sinkretisme Hindu-Buddha pada Candi Gedong I}

Sinkretisme adalah memadukan, mencampur, dan menyelaraskan dua keyakinan atau lebih. Sinkretifisme dalam penggabungannya keyakinan yang paling benar. Sinkretisme tak lepas dari kenisbian, sinkretisme bersifat divergen, longgar, adaptif, dan akomodatif. Sinkretisme merupakan "penyatuan" dua keyakinan atau lebih. "Penyatuan tidak harus menunggal, melainkan hanya pemaduan beberapa unsur saja (Endraswara, 2003:61).

Menurut Arismunandar (2002:50) bangunan Indonesia zaman dahulu terbuat dari bahan yang tidak tahan lama. Para ahli sejarah arsitektur tidak beruntung karena bahan-bahan hayati ini idak dapat bertahan di iklim Indonesia. Bangunan-bangunan kuna yang masih bertahan di Indonesia adalah yang terbuat dari batu. Bangunan batu tertua di Indonesia dibangun pada akhir zaman prasejarah, lebih kurang 2.000 tahun yang lalu. Punden berundak dari batu dan bentang lahan yang berkaitan untuk upacara dibangun pada lereng pegunungan. Punden berundak ini digunakan pada Periode Klasik. Di beberapa wilayah Nusantara, punden berundak ini masih digunakan untuk kegiatan keagamaan.

Periode Klasik Indonesia dengan berdirinya candi batu bata yang menaungi lambang dewa-dewa Hindu dan Buddha. Contoh tertua, berangka tahun awal abad ke-8, dirancang oleh arsitek Indonesia yang sudah terbiasa bekerja dengan bahan permanen. Menggunakan paduan ragam hias dan lambang pribumi dan asing mereka mengungkapkan kembali konsep prasejarah Indonesia mengenai hubungan antar manusia, dewa, dan alam semesta, pemandangan alam terutama pegunungan, dan gunung api, merupakan suatu perpaduan dalam pandangan alam semesta mereka.

Karena bangunan-bangunan Periode Klasik di bangun dari bahan yang tidak tahan lama maka kita memiliki sedikit data untuk menyelidiki bentuk bangunanannya. Selama Periode Klasik di Indonesia, lebih kurang 800 tahun lamanya, bidang arsitektur berevolusi sebagai reaksi terhadap perubahan agama, politik, dan kecenderungan umum manusia dalam menginginkan perubahan gaya.

Konsep dasar rancangan candi klasik Indonesia adalah keinginan menciptakan tiruan gunung pada pusat 
alam semesta, tempat roh para dewa dapat dibujuk untuk menjelma menjadi patung atau lingga yang ditempatkan dalam ruangan yang menyerupai gua. Arsitektur Indonesia Klasik paling awal terdiri atas tempat suci Hindu, dibangun di gunung api di Jawa Tenah. Secara raga dan perlambang, bangunan ini bersandar pada kepercayaan bahwa gunung merupakan tempat kekuatan adikodrati. Setelah "elit" yang berkuasa mulai membangun dengan batu, tempat bangunan mulai menyebar ke dataran rendah. Perluasan ini mungkin berasal dari paduan semangat: keinginan membuat tempat keagamaan lebih mudah dicapai masyarakat umum dan pengakuan untuk "elit" yang berkuasa bahwa hubungan dengan kekuasaan dewa secara nyata menambah kekuasaan duniawi mereka (Arismunandar, 2002:52).

Beberapa prinsip dasar yang melatarbelakangi bentuk candi Indonesia adalah kepercayaan pribumi pada kekuatan yang ada dalam nenek moyang dan gunung. Meski agama dan arsitektur India memainkan peran tambahan dalam menghias dan bentuk baru dalam mengungkapkan konsep yang ada sebelumnya, teori India tentang setangkup sebagai unsur dasar tata semesta secara nyata menambah konsep prasejarah Indonesia. Seni "klasik" menekankan setangkup dan penempatan unsur-unsur secara tepat, masing-masing dengan tempat yang telah seluruhnya ditentukan dalam susunan.

Menurut Wirjomartono (2009:184186) pada periode Praklasik tua diperkirakan bangunan candi terbuat dari bahan non-batu/non-permanen sehingga mudah hancur atau belum adanya tradisi membangun bangunan ibadah (candi). Pendapat lain (Santiko, 1995) menyatakan bahwa pada masa praklasik tua tersebut agama yang dipeluk adalah agama Weda, agama tertua bangsa Arya di India dengan pengkhususan pemujaan terhadap Visnu Trawikrama atau Vikranata. Upacara dalam agama ini tidak pernah dilakukan di sebuah kuil, tetapi di sebuah lapangan terbuka dengan beberapa tungku untuk memasukkan sesajinya sehingga tidak diperlukan suatu bangunan untuk tempat ibadah.

Karakter candi-candi pada masa Klasik Tua peninggalan awal Mataram adalah agak tambun dengan ukuran kecil, didominasi oleh candi-candi yang bersifat Hindu, bentuk denah candi Induk adalah bujursangkar, kaki candi terkesan polos atau bermotif geometris. Hiasan tangga berupa makara atau lidah. Selasar tidak berpagar dan sempit, pada dinding terkesan polos dengan hiasan berupa ukiran kolom di sudut-sudutnya (kolom semu), ukiran yang berbentuk jendela (jendela semu) berupa relung-relung dan ukiran motif geometrik.

Pada perkembangan selanjutnya arsitektur candi mengalami perubahan seiring dengan masuknya paham baru ke Nusantara. Masuknya aliran Mahayana ke Jawa pada abad ke-9 menjadi penyebab perubahan bentuk candi Buddha dan ikonografinya, termasuk pula berpengaruh terhadap perancangan candi-candi yang bersifat Hindu, khususnya dalam bentuk denah dan peletakkan. Hal itu dapat dilihat dari perubahan bentuk denah candi Kalasan dari bujursangkar menjadi palangsilang, atau perubahan patung utama Candi Swu. Hal itu dimungkinkan dengan adanya mandala baru dari aliran yang baru masuk yang disesuaikan dengan candi yang telah ada. Bentuk denah palangsilang ini merupakan pengaruh Mandala yang bersifat Buddha Mahayana (penyembahan terhadap Jina) dengan mandala Vajaradatu yang melambangkan Pagoda Intan di puncak Gunung Semeru yang digambarkan mempunyai lima atap lingkaran.

Perubahan bentuk denah, ikonografi akibat aliran keagamaan yang masuk mengakibatkan adanya pemugaran pada candi yang ada, tetapi tidak menutup 
kemungkinan bahwa candi-candi lama masih dipertahankan karena alasan-alasan tertentu. Dengan masuknya pengaruh Buddha ke wilayah tersebut, candi-candi pun terkadang mengikuti bentukan denah pelangsilang yang menjadi ciri khas candicandi Buddha. Hal itu akan berkaitan dengan sebuah aliran keagamaan yang menggabungkan unsur Hindu-Buddha ke dalam suatu bangunan.

Menurut Wirjomartono (2009:214215) tantrik dalam agama Buddha berbentuk nilai magis dari pencarian nirwana yang dilakukan melalui teknik meditasi. Tantrik serupa dengan konsep Hinduisme, atau bahkan mengambil konsep tersebut sehingga sulit dibedakan. Teknik meditasi. Ritual yang dilakukan menyangkut pikiran, kata-kata, dan gerakan tubuh dari seorang sebagai perwujudan mikrokosmos dalam makrokosmos. Simbol bentuk lekuk manusia diwujudkan dalam bentuk bunga lotus atau lonceng/genta (lonceng) adalah simbol dari wanita dalam 'tantra'), sedangkan pria diwujudkan dalam bentuk vajra.

Perubahan sistem religi yang dianut pada suatu kerajaan akan mengubah pula citra candi yang ditampilkan. Perancangan candi menunjukkan kedinamisan bervariatif. Dinamika ini berkaitan dengan letak geopolitik Nusantara yang berada di antara persilangan jalur pelayaran internasional, dua samudera dan benua, sehingga sangatlah mudah menerima budaya dari luar. Perancangan candi mengalami perubahan bentuk seiring dengan perkembangan politik, agama, ekonomi, yang didukung oleh teknologi dan konteks lingkungan pada zamannya, muncul penyesuaian melalui perubahan raga. Strategi perancangan tidak sekedar mengulang, meminjam dan meniru dari masa sebelumnya, melainkan lebih merupakan usaha bongkar susun kembali, sehingga muncul wujud 'yang lain' tampak 'baru' (visioner), khususnya pada setiap periodenya. Tiap periode menghadirkan karekter yang khas dan kemudian digunakansecara berulang pada zamannya. Perkembangan candi mempresentasikan adanya dinamika penggunaan unsur-unsur budaya masa lalu dan aspek lokal genial. Arsitektur candi di Indonesia pada masa lalu diduga tidak sekedar meniru apa yang masuk dari luar namun dikreasikan dan diramu dengan budaya kuno (Austronesia Purba) dan kondisi yang berlaku. Hal ini menunjukkan bahwa masyarakat pada saat itu telah mempunyai daya cipta yang memadai dalam mengolah berbagai budaya yang masuk. Muncul ide-ide akulturasi berupa arsitektur sinkretisme yang didasari oleh sinkretisme Hindu, Buddha, dan Agama Asli/kuno. Sinkretisme menunjukkan 'dialog' antar unsur di dalamnya meskipun berbeda namun dapat menyatu (melebur) dalam satu kesatuan tunggal, Bhinneka Tunggal Ika Tan Hana Dharma Mangruwa

Sinkretifisme Hindu-Buddha pada Candi Gedong I Muara Jambi yaitu:

1. Ditemukannya hiasan/relief yang berbentuk salib pada bagian tangga kanan dan kiri candi induk. Relief ini mencerminkan simbol Hindu (simbol siwa).

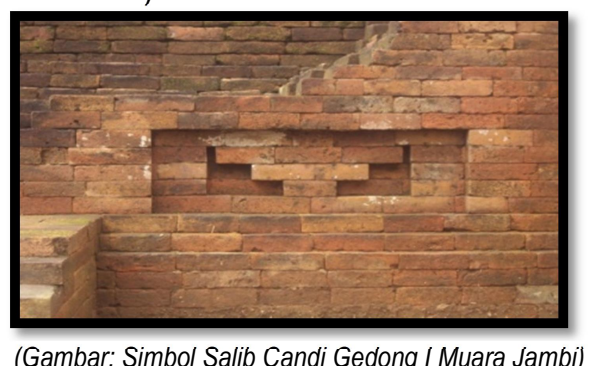

\section{Nilai Keagamaan Candi Gedong I Muara Jambi}

Menurut Nottingham (1996:45) nilai keagamaan merupakan landasan bagi sebagian besar sistem nilai-nilai sosial, maka pelajaran-pelajaran yang paling penting bagi anak-anak adalah dalam lapangan yang sekarang sering kita sebut pendidikan agama (religius education).Nilai 
keagamaan adalah penghargaan oleh manusia pada kehidupan beragama yang bersifat suci sehingga menjadikan pedoaman bagi tingkah laku keagamaan masyarakat.

Menurut Utomo (2011:154-155) kompleks candi Gedong I Muara Jambi berdiri di halaman seluas 5.525 meter persegi, terdiri dari dua bangunan yaitu bangunan induk dan sebuah gapura yang berada di timur. Pagar yang menggelilingi kompleks berukuran 65 x 85 meter, sedangkan bangunan induk tidak tepat berada di tengah halaman, melainkan agak bergeser ke belakang mendekati pagar sisi barat.

Seluruh bata bagian luar (bata kulit) bangunan induk hilang, kecuali sebagian kecil pada tangga naik di sisi timur yang didapati hiasan berbentuk salib; hiasan yang lazim ditemukan pada bangunanbangunan Hindu-Buddha abad 15-16 Masehi di Jawa Timur.Dari lokasi ini ditemukan 6 buah umpak dari batu pasiran dengan lubang persegi di bagian atasnya,pecahan arca batu berbentuk kepala Buddha, sejumlah bata bergambar dan bata bertulis, bata-bata melengkung sisa dari stupa dan pecahan genteng kuno tidak berglasir yang terbuat dari tanah. Selain itu ditemukan pecahan keramik Cina dari masa dinasti Sung (10-13), Yuan (1314), Ming (14-17), dan Ching (17-20), keramik Eropa (19-20), pecahan-pecahan kaca kuno berasal dari Timur Tengah atau India.

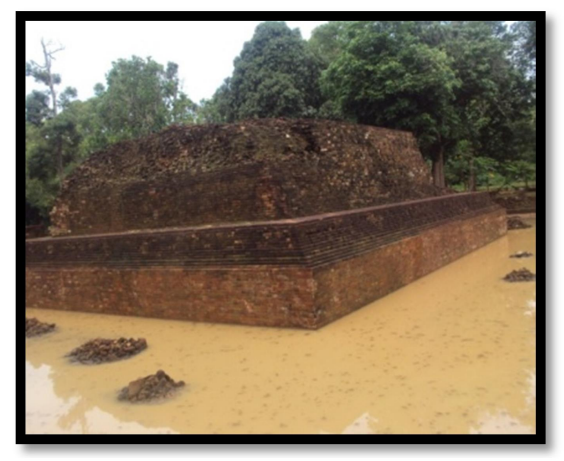

(Gambar: Candi Induk Gedong I Muara Jambi)
Jambi mampu mempertahankan keunggulan sampai abad ke-12. Candicandi dalam gugus di Muara Jambi dipugar dan diperbesar selama periode ini: bukti kuat tentang kemakmuran kerajaan. Pusat agama tersebut yang sebagian besar sudah dipugar. Candi yang baru dipugar baru ada 8 candi, karena faktor bahan bangunan yang sudah hilang sehingga mengakibatkan sulitnya proses rekonstruksi dan juga faktor biaya. Pendapat dari orangorang yang mempugar Candi Muara Jambi, di identifikasikan bahwa Candi Muara Jambi merupakan candi peninggalan agama Buddha, karena terdapat beberapa penemuan arca-arca namun belum dipastikan 100\%. Wilayah Candi Muara Jambi sudah masuk Cagar Budaya. (catatan wawancara dengan masyarakat sekitar Candi Gedong I Muara Jambi pada tanggal 17 Maret 2017 jam 10:32 Wib).

Situs purbakala Candi Muara Jambi merupakan kawasan percandian peninggalan kerajaan Melayu dan Sriwijaya yang bercorak Hindu-Buddha. Adapun nilai keagamaan yang terdapat pada Candi Gedong I Muara Jambi yaitu Candi Gedong I Muara Jambi merupakan candi peninggalan agama Buddha, meskipun terdapat juga pengaruh agama Hindu pada bangunan Candi Gedong I Muara Jambi. Agama Buddha Mahayana Tantrayana yang diperkirakan menjadi agama mayoritas yang dianut oleh sebagian besar masyarakat di wilayah tersebut pada zamannya. Selain itu nilai keagamaan Candi Gedong I menunjukkan sebagai salah satu warisan budaya agama Buddha yang bernilai sangat tinggi bagi penelusuran sejarah Indonesia dan sejarah Jambi, karena Situs Candi Muara Jambi pada umumnya mempunyai nilai penting budaya, etnik dan publik. Nilai etnik dapat memberikan informasi warisan budaya yang memberikan pemahaman terhadap latar belakang kehidupan sosial, keagamaan dan mitologi yang menjadi jati diri suatu bangsa. Pada bagian-bagian 
yang terdapat pada bangunan Candi tersebut dapat menunjukkan bahwa zaman dulu Candi Muara Jambi ini pernah dijadikan sebagai salah satu pusat tempat peribadatan agama Buddha Tantri Mahayana di Indonesia. Ditambah dipertegas dengan datangnya sekelompok para Rohaniawan Buddha yang berasal dari luar Negeri dan para biksu asal Tiongkok yang juga datang ke Candi Muara Jambi Candi Gedong I khususnya sehingga semakin menunjukkan bahwa candi tersebut sebagai sarana ibadah bagi agama Buddha pada zamannya. Bahkan hal ini juga diperkuat dengan adanya beberapa hasil temuan benda sejarah yang terdapat pada candi Gedong I yang menunjukkan pengaruh agama Hindu yaitu berupa simbol salib yang terdapat di tangga kanan dan kiri bangunan candi induk, selain itu terdapat juga bukti pengaruh agama Buddha yang ditemukan di Candi Gedong I. Adapun temuan-temuan yang terdapat di Candi Gedong I Muara Jambi yaitu, sebagai berikut:

\section{1) Temuan yang diperkirakan stupa}

Terdapat temuan yag diperkirakan stupa di Candi Gedong I Muara Jambi. Menurut cerita, stupa memiliki asal mula yaitu: dua orang yang termasuk penganutpenganut pertama agama Buddha diberi (tanda mata) oleh sang Buddha untuk dikenang dan dipuja, berupa potongan kuku dan rambut, dan idsuruhnya menyimpan dalam stupa. Waktu ditanya apakah itu stupa, Sang Buddha membuka pakaiannya. Lalu dilipatnya pakaian itu segi-empat, dan diletakkan di atas tanah. Dengan pakaian itu sebagai alas, ditaruhnya mangkoknya terbalik,dan di atasnya lagi di dirikanlah tongkatnya. Itulah bentuk yang harus diberikan kepada bangunan stupa. Stupa berupa bangunan yang berbentuk kubah,yang berdiri di atas sebuah lapik dan diberi payung (sebagai penghormatan) di atasnya.

Dalam perkembangan selanjutnya stupa itu ada 4 macam: a) Sebagai penyimpan tulang belulang atau abu jenazah dari Sang Buddha, dan nantinya dari para arhat dan para bhiksu terkemuka pula; sebagai demikian dinamakan juga dhatugarbha (dagoba).

b) Sebagai penyimpan benda-benda suci yang berasal dari diri atau milik Sang Buddha, Arhat atau Bhiksu terkemuka.

c) Sebagai tanda peringatan di tempattempat terjadinya sesuatu peristiwa penting dalam hidup Sang Buddha

d) Sebagai lambang suci agama Buddha pada umumnya.

Lama-kelamaan stupa itulah yang menjadi dipuja, dan sebagai benda pujian disebut juga: caitya (Soekmono, 1973:23).

\section{2) Pecahan keramik}

Temuan-temuan keramik yang terdapat di Candi Gedong I Muara Jambi diperkirakan berasal dari beberapa dinasti yaitu sebagai berikut:

a) Dinasti Tang (618-907 M)

Jenis Keramik pada masa Tang menggunakan bahan dari tanah liat sampai kaolin dengan warna glasir umumnya putih, hijau, dan cokelat. Hiasan umumnya digores atau ditempel (Abdulhadi, 2001: 33). Pecahan keramik dinasti Tang yang ditemukan di Candi Gedong I Muara Jambi ada Tang yang bewarna putih, hitam, dan cokelat.

b) Dinasti Sung (960 M - 1127 M) Keramik Sung yang ditemukan di Indonesia dari jenis-jenis: Lung Chyan. Bahan dasar keramik Lung Chyan adalah batuan dengan warna putih keabuan. Ciri khusus keramik ini adalah bentuknya yang tebal. Jenis Ting Yoo berglasir putih, biasanya igores dengan garis bentuk salur-saluran. Ada pula yang dihias gambar burung dan ikan (Abdulhadi, 2001:33). Namun, 4 Temuan pecahan keramik dinasti Tang yang 
ditemukan di Candi Gedong I Muara Jambi tidak memiliki motif.

c) Five Dinasti (907 M-960 M)

Temuan pecahan keramik dinasti

Tang yang ditemukan di Candi

Gedong I Muara Jambi 4 buah.

d) Dinasti Ming (1368 M-1644 M)

Produksi keramik pada Masa Ming awal memiliki ciri-ciri antara lain: bentuknya besar, dekorasinya menyebar ke seluruh permukaan. Teknik hiasnya dibuat dengan hatihati, sehingga rapi dan halus (Abdulhadi, 2001: 33).

3) Manik-manik

Manik-manik yang ditemukan di Candi Gedong I Muara Jambi diperkirakan berasal dari perdagangan pada masa Kerajaan Sriwijaya. Manik-manik ini berwarna hijau dan tampak terang.

Bangunan profan yang terdapat di utara candi induk dan bagian selatan candi diperkirakan sebagai tempat menaru sesaji untuk pemujaan.

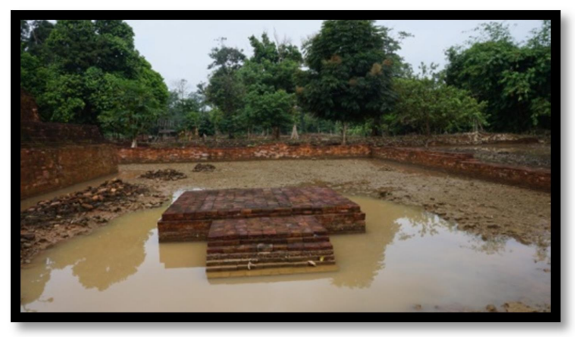

(Gambar: Profan Candi Gedong I Muara Jambi)

Sumber Pembelajaran Sejarah Tentang
Nilai Keagamaan Candi Gedong I Muara
Jambi di SMA Aisyiyah 1 Palembang
Menurut Arsyad (2014:8) istilah
sumber belajar dipahami sebagai
perangkap, bahan (materi), peralatan,
pengaturan, dan orang dimana pembelajar
dapat berinteraksi dengannya yang
bertujuan untuk memfasilitasi belajar dan
memperbaiki kinerja. Pembelajaran dapat
diartikan sebagai hasil memori, kognisi, dan metakognisi yang berpengaruh terhadap pemahaman. Salah satu bentuk pembelajaran adalah pemprosesan informasi hal ini bisa dianalogikan dengan pemikiran atau otak kita yang berperan layaknya komputer dimana ada input dan penyimpanan informasi di dalamnya. Dengan demikian dalam pembelajaran seseorang perlu terlibat dalam refleksi dan penggunaan memori untuk melacak apa saja yang harus ia simpan dalam memorinya dan bagaimana ia menilai informasi yang telah diperoleh (Abdulhadi, 2001:2).

Sumber pembelajaran di SMA Aisyiyah 1 Palembang banyak menggunakan berbagai refensi buku-buku sejarah, serta survei langsung ke lapangan seperti ke Museum-musem dan situs sejarah yang ada di Palembang sesuai dengan materi pembelajaran sejarah yang sedang dipelajari di kelas.

Guru dalam memahami materi pelajaran, seorang guru sejarah harus membuat ringkasan dan mempelajari yang telah dibuat dan seorang guru harus banyak membaca agar dapat menambah wawasan dalam mengajar. Dan pelaksaan pembelajaran di SMA Aisyiyah 1 Palembang berjalan sesuai dengan kurikulum yang telah ditentukan yaitu untuk kelas X kurikulum 2013 (catatan wawancara Meriyeni Ahca, S.Pd Guru Sejarah SMA Aisyiyah 1 Palembang tanggal 05 Mei 2017 jam 08.22).

Seorang guru sejarah di dalam memahami materi pelajaran khususnya materi tentang materi Hindu-Buddha seperti yang terdapat di silabus kurikulum 2013 pada 3.6 Menganalisis karakteristik kehidupan masyarakat, pemerintahan dan kebudayaan pada masa kerajaan-kerajaan Hindu-Buddha di Indonesia dan menunjukan contoh bukti-bukti yang masih berlaku pada kehidupan masyarakat Indonesia masa kini. Harus banyak membaca buku-buku, jurnal yang ada mengenai Candi Gedong I dilihat dari nilai 
keagamaannya (catatan wawancara Meriyeni Ahca, S.Pd Guru Sejarah SMA Aisyiyah 1 Palembang tanggal 05 Mei 2017 jam 08.40).

Menurut Meriyeni Ahca, S.Pd guru Sejarah SMA Aisyiyah 1 Palembang dalam pelaksanaan belajar mengajar, guru terlebih dahulu harus ada pedoman mengajar berupa Rencana Pelaksanaan Pembelajaran (RPP) agar materi yang disampaikan oleh guru lebih terarah dan sesuai dengan jenjangnya. Dan disamping itu, untuk menarik minat siswa dalam mempelajari sejarah perlunya cara yang kreatif dan inovatif agar siswa lebih cepat memahami pembelajan yang dijelaskan oleh guru sejarah serta agar siswa tidak mudah jenuh.

Materi nilai keagamaan Candi Gedong I Muara Jambi baru sekilas dipelajari pada saat materi hindu-buddha di Indonesia. Dalam pembelajaran sejarah Tidak memiliki kendala yang begitu berarti, namun lebih ke untuk merealissikan keinginan untuk mengajak siswa-siswi langsung ke situs bersejarah yang berada di kawasal Sumatera Selatan salah satunya Candi Gedong 1 Muara Jambi (catatan wawancara Meriyeni Ahca, S.Pd Guru Sejarah SMA Aisyiyah 1 Palembang tanggal 05 Mei 2017 jam 08.50).

Menurut Meriyeni Ahca, S.Pd guru Sejarah SMA Aisyiyah 1 Palembang secara langsung modul Nilai Keagamaan Candi Gedong I Muara Jambi yang sudah dibuat oleh peneliti sudah bagus karena dilengkapi dengan poto-poto, serta sumber dan referensi bukunya sudah lengkap. Suatu saat akan di jadikan referensi tambahan untuk pembelajaran sejarah khususnya pada materi peninggalan HinduBuddha yang ada di Indonesia, Sumatera Selatan ke siswa. Dan diharapkan agar dapat menambah wawasan siswa mengenai candi yang Hindu-Buddha yang terdapat di Sumatera Selatan yaitu Candi Gedong I Muara Jambi, serta menambah daya tarik siswa untuk belajar sejarah.

\section{KESIMPULAN}

Berdasarkan penelitian yang dilakukan oleh peneliti dapat disimpulkan bahwa. Situs purbakala Candi Muara Jambi merupakan kawasan percandian peninggalan kerajaan Melayu dan Sriwijaya. Adapun nilai keagamaan yang terdapat pada Candi Gedong I Muara Jambi yaitu Situs purbakala Candi Muara Jambi merupakan kawasan percandian peninggalan kerajaan Melayu dan Sriwijaya yang bercorak Hindu-Buddha. Adapun nilai keagamaan yang terdapat pada Candi Gedong I Muara Jambi yaitu Candi Gedong I Muara Jambi merupakan candi peninggalan agama Buddha, meskipun terdapat juga pengaruh agama Hindu pada bangunan Candi Gedong I Muara Jambi. Agama Buddha Mahayana Tantrayana yang diperkirakan menjadi agama mayoritas yang dianut oleh sebagian besar masyarakat di wilayah tersebut pada zamannya. Selain itu nilai keagamaan Candi Gedong I menunjukkan sebagai salah satu warisan budaya agama Buddha yang bernilai sangat tinggi bagi penelusuran sejarah Indonesia dan sejarah Jambi, karena Situs Candi Muara Jambi pada umumnya mempunyai nilai penting budaya, etnik dan publik. Nilai etnik dapat memberikan informasi warisan budaya yang memberikan pemahaman terhadap latar belakang kehidupan sosial, keagamaan dan mitologi yang menjadi jati diri suatu bangsa. Pada bagian-bagian yang terdapat pada bangunan Candi tersebut dapat menunjukkan bahwa zaman dulu Candi Muara Jambi ini pernah dijadikan sebagai salah satu pusat tempat peribadatan agama Buddha Tantri Mahayana di Indonesia.

Ditambah dipertegas dengan datangnya sekelompok para Rohaniawan Buddha yang berasal dari luar Negeri dan para biksu asal Tiongkok yang juga datang ke Candi Muara Jambi Candi Gedong I khususnya sehingga semakin menunjukkan bahwa candi tersebut sebagai sarana 
ibadah bagi agama Buddha pada zamannya. Bahkan hal ini juga diperkuat dengan adanya beberapa hasil temuan benda sejarah yang terdapat pada candi Gedong I yang menunjukkan pengaruh agama Hindu yaitu berupa simbol salib yang terdapat di tangga kanan dan kiri bangunan candi induk, selain itu terdapat juga bukti pengaruh agama Buddha yang ditemukan di Candi Gedong I. Adapun temuan-temuan yang terdapat di Candi Gedong I Muara Jambi yaitu, sebagai berikut:

Dengan dijadikannya nilai keagamaan Candi Gedong I Muara Jambi sebagai sumber pembelajaran di SMA Aisyiyah 1 Palembang, maka akan membantu guru dan siswa mengetahui sejarah lokal yang ada di daerahnya, sehingga dapat menumbuhkan rasa bangga terhadap daerahnya dan dapat menambah minat siswa untuk belajar sejarah.

\section{DAFTAR PUSTAKA}

Abdulhadi, Yetti Herayati, dkk. 2001. Selintas Keramik Di Jawa Barat (Koleksi Museum Sri Baduga). Bandung.

Arismunandar, Agoes, dkk. 2002. Arsitektur. Jakarta: PT Widyadara.

Arsyad, Azhar. 2014. Model-model Pengajaran dan Pembelajaran. Yogyakarta: Pustaka Pelajar.

Endraswara, Suwardi. 2003. Mistik Kejawen, Sinkretisme, Simbolisme, dan Sufisme dalam Budaya Spiritual Jawa. Yogyakarta: Narasi.

Erwin, Tuti Nuriah. 1990. Asia Selatan dalam Sejarah. Jakarta: Fakultas Ekonomi.

Hendarata, Ade Oka. 2012. Laporan penelitian Arkeologi Penelurusan Kerajaan Islam di Provinsi Jambi Tahap I. Palembang: Balai Arkeologi.
Latief, llyas, dkk. 1994. Dampak Pengembangan Pariwisata Terhadap Kehidupan Budaya Daerah Jambi. Jambi.

Munandar, Agus Aris, dkk. 2009. Sejarah Kebudayaan Indonesia Religi dan Filsafah. Jakarta: Rajawali Pers.

Nottingham, Elizabeth K.1996. Agama dan Masyaraka Suatu Masyarakat Sosiologi Agama. Jakarta: PT. RajaGrafindo.

Poesponegoro, Marwati Djoned, dan Nugroho Notosusanto. 2010. Sejarah Nasional Indonesia II. Jakarta: Balai Pustaka.

Purwanti, Retno. 2012. "Situs Muara Jambi Menuju Warisan Dunia". Jurnal Arkeologi Siddhayatra. Vol. 17 No.1 (30-42).

Soekmono.1973. Pengantar Sejarah Kebudayaan Indonesia 2. Yogyakarta: Kanisus.

Sugiyono. 2008. Memahami Penelitian Kualitatif. Bandung: Alfabeta.

Samad, Ulfat Aziz-us, 1990. Agama-agama Besar Dunia. Jakarta: Darul Kutubil Islamiyah.

Tim Koordnasi Penelitian Sejarah Melayu Kuno. 1994. Laporan Sementara Hasil Penelitian Arkeologi dan Geologi Provinsi Jambi. Balai Arkeologi Palembang: Jambi.

Utomo, Bambang Budi. 2011. Kebudayaan Zaman Klasik Indonesia di Batang Hari.Jambi: Dinas Kebudayaan dan Pariwisata.

Wirjomartono, Bagoes, dkk. 2009. Sejarah Kebudayaan Indonesia Arsitektur. Jakarta: Rajawali Pers.

Wiyoso. 1982. Album Seni Budaya Jambi Cultural Album Of Jambi. 